$$
\text { ノート }
$$

\title{
立体 $\mathrm{X}$ 線写真の解 析
}

\author{
福島県立医科大学 放射線科 \\ 山田久夫。佐々木幹人*
}

（論文受理 昭和56年 3 月 29 日）

(Code No. 21460)

\section{ANALYSIS OF 3 DIMENSION IMAGE}

(Article received: Mar. 29, 1981)

\author{
By HisAO YAMADA and \\ MIKINDO SASAKI \\ Department of Radiology Fukushima \\ Medical College Hospital
}

\section{Summary}

An analysis was made of the geometric relation between stero-radiographing system and its observation one which has an effect on the imaging in the diagnostic stereography.

(1) In stereography with magnified $\mathrm{X}$-rays in which the magnification ratio of images on $\mathrm{X}$ and $\mathrm{Y}$ axis is different from the one on $Z$ axis a kind of image distortion is inevitable.

(2) Stereographing system under a certain appropriate condition can produce an image with equal mag. nification ratio of one on $\mathrm{X}, \mathrm{Y}$ and also $\mathrm{Z}$ giving life-size without distortion.

(3) As discribed above, a magnified stereographic image accompanies a distortion.

However, a magnified stereographic image will be perceived if the image on the retina is enlarged, which can be obtained by shortening the visual distance thus widening the visual angle.

\section{1.はじめに}

最近ステレオ用X線管が数社から発売されるようにな うた.

ステレオX線写真への関心の現れではないかと思われ る.

立体X線撮影法において，撮影系，観祭系の幾何学的 条件によって，立体模像（再生像）がどのように変化す．

*) 現在 太田綜合病院附属太田西ノ内病院
るかを解析的に調べた。

また歪の小さな立体模像（再生像）を得るためには， どのような焦点間距離のステレオ管球が望ましいかす明 らかにした。

\section{2. 方法及び理論}

立体X線写真に招ける撮影系と観察系の幾何学的関係 に代数式をあてはめ，いくつかのパラメータに数值を代 入し，コンピュータで計算し，得られた值をプロッタで 
グラフ化しグラフの曲線から，被写体上立体模像の関係 を把握する。

\section{Z 軸の解析}

立体X線撮影系と観察系を作図すると，Z軸はFig. 1 のようになる.

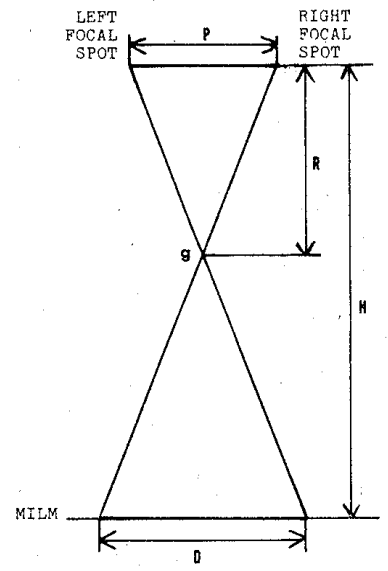

(I) Exposric

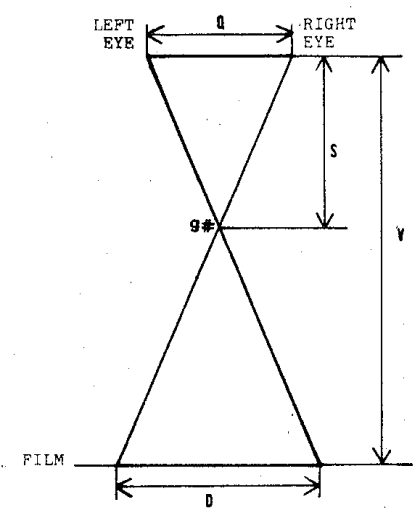

(2) VIEWIM
Fig. 1.1, Fig. 1.2 Geometries for $Z$ axis of stereoscopic exposing and viewing system.

撮影系におりて

焦点一フィルム間の任意の点を $\mathrm{g}$

焦点間距醀老 $\mathrm{P}$

焦点一フィルム間距離を $\mathrm{H}$

焦点一 $\mathrm{g}$ 間距離老 $\mathrm{R}$

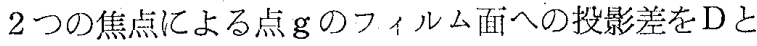
する亡, 次の式が成り立つ.

$$
D=P \cdot\left(\frac{H}{R}-1\right)
$$

次に観祭系（Fig. 1.2）において

点 $\mathrm{g}$ の逆投影による交点を $\mathrm{g}$ \#

推繁者の曈孔間距離をQ

観察者の瞳孔一フィルム間距離を $\mathrm{V}$

観矮者の瞳孔一 $\mathrm{g}$ \#間距離を $\mathrm{S}$

立体撮影によって得られる投影差はDであるから

$$
S=\frac{V}{\left(\frac{D}{Q}+1\right)}
$$

が得られ，式 2 に式 1 を代入すると

$$
S=\frac{V Q}{\frac{P H}{R}-P+Q}
$$

が得られる。

$$
\begin{aligned}
& \text { 式 } 3 \text { 亿拈いて特記すべきととは } \\
& \mathrm{P}=\mathrm{Q}, \mathrm{H}=\mathrm{V} \text { という条件の6とでは， } 3 \text { 式は， }
\end{aligned}
$$

$\mathrm{S}=\mathrm{R}$ と票う特異的な式になる。

つまり瞳孔間距離加焦点間距離に等しく，焦点一フィ ルム開距離が瞳孔一フィルム間距離に等しいならば，被 写体のZ 軸之立体模像のZ 軸は 1 対 1 の対応をしている ことになる。

また $\mathrm{P}=\mathrm{Q}, \mathrm{H} \neq \mathrm{V}$ という条件でも

$$
S=\frac{V}{H} R
$$

になり，HとVが定数であれば， $\mathrm{S} と \mathrm{R} は$ 亱線関係とな る.

一般的に行なわれている立体X線写真におけるH，V， $\mathrm{P}, \mathrm{Q}$ の值に関してのRと $\mathrm{S}$ の関係は次の項で図表化し て示卞.

\section{4. $\mathrm{X}$ 軸成分と $\mathrm{Y}$ 軸成分の解析}

撮影系において，焦点から任意の距離 $\mathrm{R} に$ に㧍ける平面 $\mathrm{G} の \mathrm{X}$ 軸成分（あるいはY軸成分） $\mathrm{B}$ と，之の投影像 $\mathrm{K}$ の関係はFig.2.10ようになる。
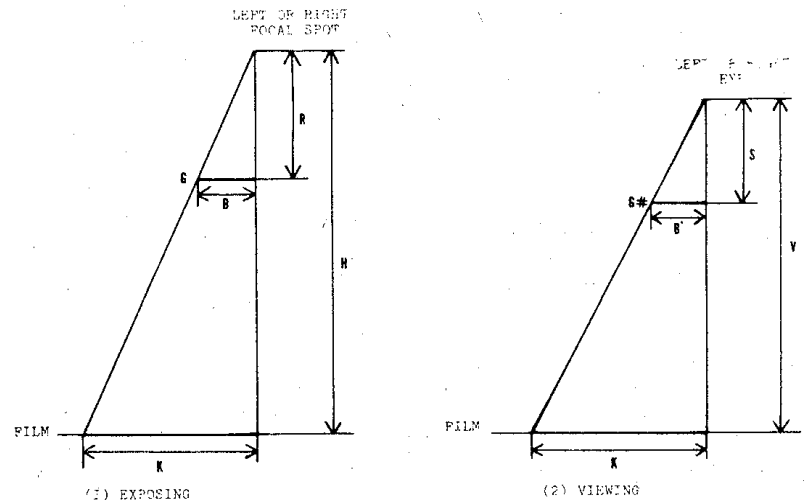

Fig. 2.1. Fig. 2.2. Geometries for $X$ or $Y$ axis of stereoscopic exposing and viewing system.

焦点一フィルム間距皠を $\mathrm{H}$

焦点一G間距離を $\mathrm{R}$

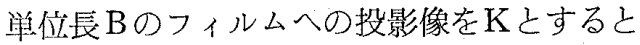

$$
K=\frac{H}{R} B
$$

式 5 を得る.

観察系について作眓をするとFig. 2,2のようになる.

$\mathrm{K}$ の逆投影によって得られる，X軸成分（あるいは $\mathrm{Y}$ 軸成分) Bの再生像をB\#とし

瞳孔一フィルム間距晟を $\mathrm{V}$

瞳孔一 $-\mathrm{G}$ \#間距離を $\mathrm{S}$

とすると

$$
B \#=\frac{S}{V} K
$$


式 6 が成り立つ.

式6に式5を代入すると

$$
B \#=\frac{H \cdot S}{V \cdot R} B
$$

式7が成り立つ.

式 7 亿式 3 を代人すると

$$
B \#=\frac{H \cdot B}{V \cdot R}\left(\frac{V \cdot Q}{\frac{P H}{R}-P+Q}\right)
$$

式 8 を得る.

$\mathrm{B}$ と B\#の比をとれば被写体と立体模像のX軸成分 （あるいはY軸成分）の拡大㲔を知るととができる.

式8亿㧈认てあ， $\mathrm{H}=\mathrm{V}, \mathrm{P}=\mathrm{Q}$ という特異的な条件 のもとでは，B\#=B となり被写体中のX輎成分（ある いはY軸成分) 之立体模像中のX軸成分（あるいはY蟿 成分）が 1 対 1 の対応をしていることになる.

以上の結果，被写体之等大の立体模像を観祭するため には，钼祭者の朣孔間距晟に等しい焦点間距離で，観察 距刻に等しい撮影距離がよいということになる。

一般的に行なわれている立体X線写真法では，撮影践 滩, 観祭距離, 焦点間距離, 瞳孔間距離がまちまちであ り，立体模像は，それらの条件の不整合より歪が生じて いる.

立体模像に歪を生じさせる团子として，毛う一つ重要 なるのに，フィルム配置誤差によるすのがある。

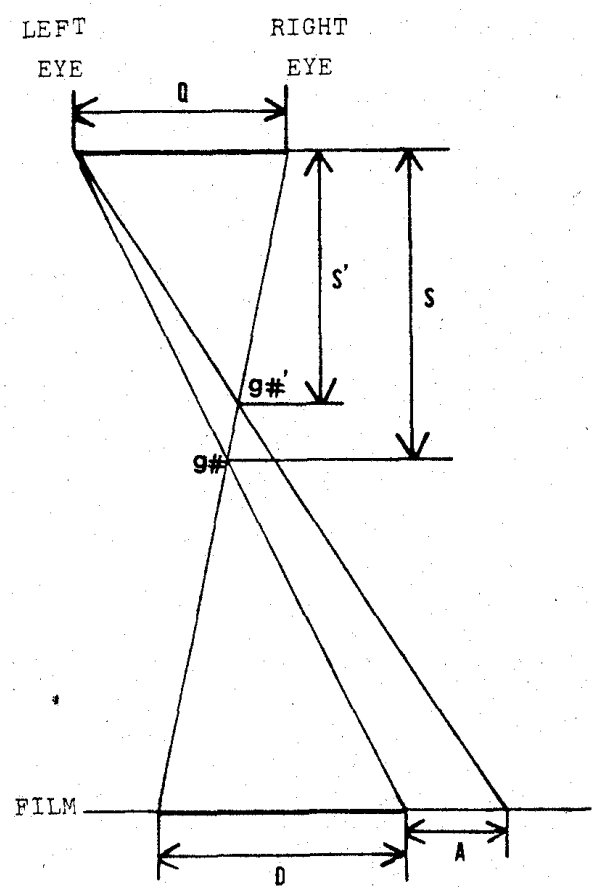

Fig. 3. Effect on the $Z$ axis by arrange. ment error in the direction of discrepancy in the image.
フィルム配置愦差というのは，観察系にフィルムをセ ットする際に生じるもので，Fig. 3 亿示すように投影差 方向に生じるずれ成分Aをいう。

投影差Dにフィルム配置誤差か加わると，式 2 は次の よう代变化する。

$S=\frac{V}{\left(\frac{D+A}{Q}+1\right)}=\frac{V Q}{\frac{P H}{R}-P+Q+A}$

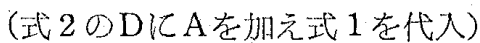

式 9 の様になりRとSの関係はさらに複潄になる.

これはX，Y，Zの各軸に影響を与える。

\section{5. 計 算 結 果}

日本人の瞳孔間距離の平均は約 $6.3 \mathrm{~cm}$ といわ机てい るのでとくに断わらない限りこの值を用いた。

焦点一点 $\mathrm{g}$ 間距離 $\mathrm{R}$ の変域は，X線管の棈造，被曝線 舅等を学慮して焦点から $20 \mathrm{~cm}$ よりフィルム面までの距 漼とした。

Fig. 4 は，焦点間距離 $2.5 \mathrm{~cm}$, 撮影距離 $100 \mathrm{~cm}$, 観 祭距離を $50 \mathrm{~cm}$ かららか $10 \mathrm{~cm}$ おきに，120 cm まで変 化させた場合のRとSに関するグラフである。例えば， 観察距離 $70 \mathrm{~cm}$ の場合は70 書加れた旧線を見る.

この曲線の場合, 焦点加ら $30 \mathrm{~cm}$ 離れた点は瞳孔加ら $36.4 \mathrm{~cm}$ 離れた点として観察される.

同㥞に $50 \mathrm{~cm}$ の点は $50.1 \mathrm{~cm}$ ，即ち，この 2 点間距離 $20 \mathrm{~cm}$ が， $13.7 \mathrm{~cm}$ 亿短縮されていることがわかる.

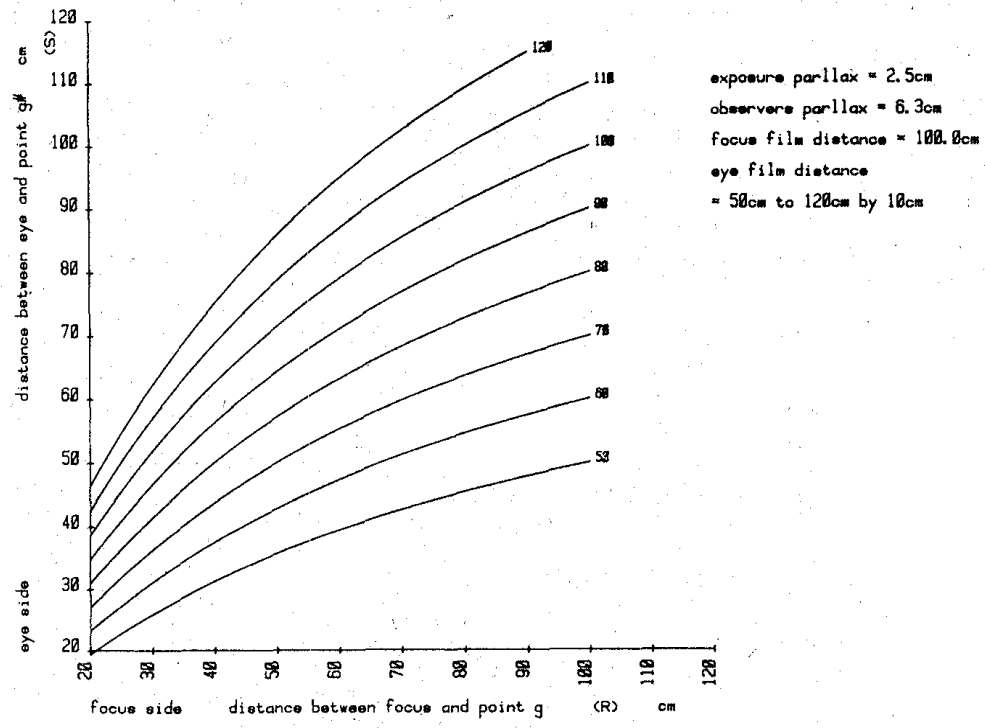

Fig. 4. The relation between real $Z$ axis and visual $Z$ axis.

$\mathrm{V}=50 \mathrm{~cm} \cdot$ to $120 \mathrm{~cm}$, step $10 \mathrm{~cm}$ $\mathrm{P}=4 \mathrm{~cm}$ 


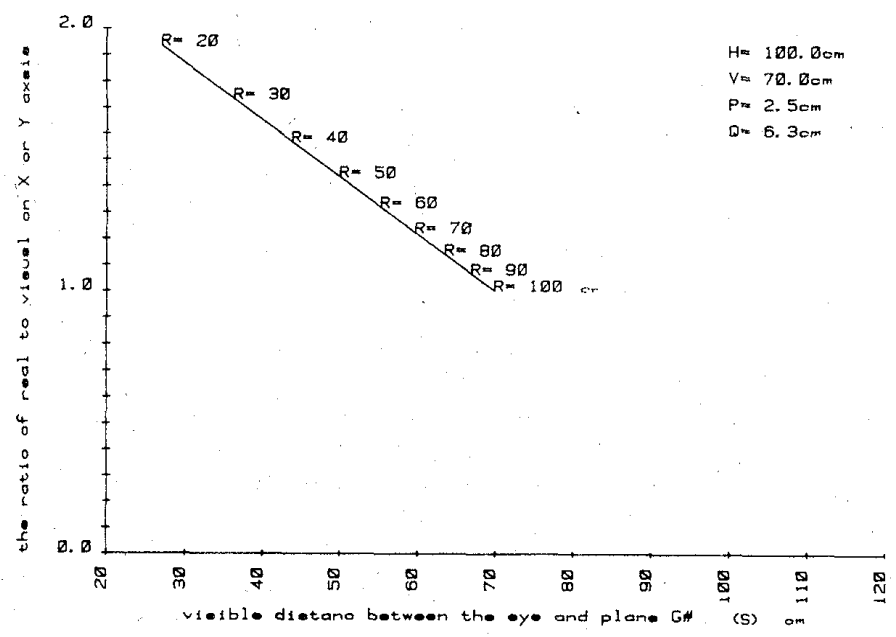

Fig. 5. Magnification ratio of $\mathrm{X}$ or $\mathrm{Y}$ axis.

$$
\mathrm{A}=0 \mathrm{~cm}
$$

Fig. 5 はX，Y軸成分の再生比を表わしている.

例えば，焦点から $30 \mathrm{~cm}$ 䌖れた面 $\mathrm{G}$ は，目加ら $36.4 \mathrm{~cm}$ 滩れた場所に面 $\mathrm{G} \#$ こして観祭され $\mathrm{X} ， \mathrm{Y}$ 軸の拡大率は 1.73倍となっているととがわかる，同㥞にして $50 \mathrm{~cm} の$ 埸合 $50.1 \mathrm{~cm}, 1.43$ 倍となっている。

Fig, 6 は撮影距離 $100 \mathrm{~cm}$ 観祭距離 $70 \mathrm{~cm}$, 焦点間距離 $2.5 \mathrm{~cm}$ で，フィルム配置䛊差を $-2.5 \mathrm{~cm}$ から $0.5 \mathrm{~cm}$ ど とに2. $5 \mathrm{~cm}$ まで変えた場合のグラフを表わす。

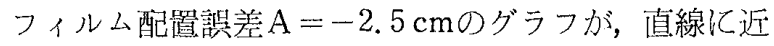
い曲線になっているととがわかる。

$$
\mathrm{R}=30 \mathrm{~cm} \text { のとき } \mathrm{S}=45.8 \mathrm{~cm}
$$$$
\mathrm{R}=50 \mathrm{~cm} \text { のとき } \mathrm{S}=70 \mathrm{~cm}
$$

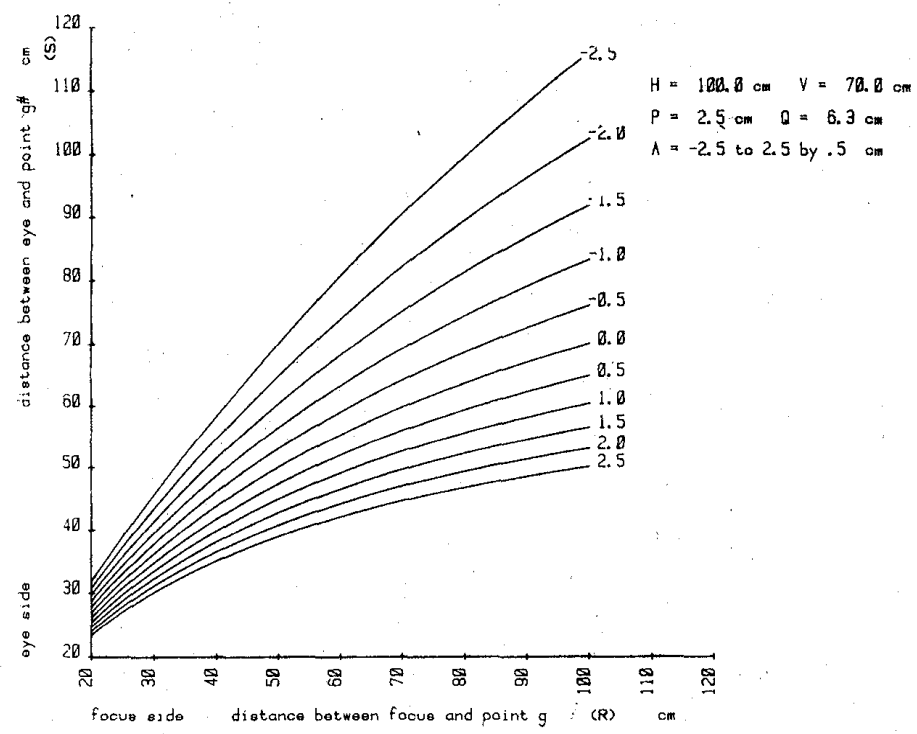

Fig. 6. The relation between real $Z$ axis and visual $Z$ axis.

$A=-2.5 \mathrm{~cm}$ to 2.5 , step $0.5 \mathrm{~cm}$
即ち,この 2 点間のRの差が $20 \mathrm{~cm}$ のき， $\mathrm{S}$ 差は $24.2 \mathrm{~cm}$ となっている.

この 2 点間を直線とみなし勾配を計算すると 約1.21となる.

つまりこの区間におりるZ軸の拡大率は 1.21 偣しいえる。

この条件に打故る，Y軸の昖大率のグラフ 老Fig. 7 亿示古.

$\mathrm{R}=30 \mathrm{~cm}$ の己き $\mathrm{S}=45.8 \mathrm{~cm}, \mathrm{X}, \mathrm{Y}$ 軸拡大 率2.2

$\mathrm{R}=50 \mathrm{~cm}$ のとき $\mathrm{S}=70.0 \mathrm{~cm} \mathrm{X}, \mathrm{Y}$ 軸桩大 率2.0

$\mathrm{X}, \mathrm{Y}$ 軸の拡大率は 2 倍位であるが， $\mathrm{Z}$ 軸と ともに変化するととがわかる。

$\mathrm{Z}$ 軸の拡大率とX，Y軸の拉大率本一致して いないととがわかる。

阔様に焦点間距離 $4 \mathrm{~cm}$ 管球で，パラメータを変えた グラフをFig. 8, 9, 10,11亿示す。.

Fig. 10は, 撮影距離 $102 \mathrm{~cm}$, 観察距離 $70 \mathrm{~cm}$ フィル ム配置愦差を $-2.5 \mathrm{~cm}$ から $0.5 \mathrm{~cm}$ どとに $2.5 \mathrm{~cm}$ まで 変えた場合のグラフである。

フィルム配置愦差 $-2 \mathrm{~cm}$ の曲線はほぼ固線に近く勾 配む約1亿なっている.

然し，この条件に括りるX，Y軸の抬大率のグラフは Fig.11に示す様に，つまりとの場合にも $Z$ 軸拡大率之， $\mathrm{X}, \mathrm{Y}$ 軸拨大率の值は異なってくる.

次は，特異条件を含むグラフを Fig. 12,13に示す。

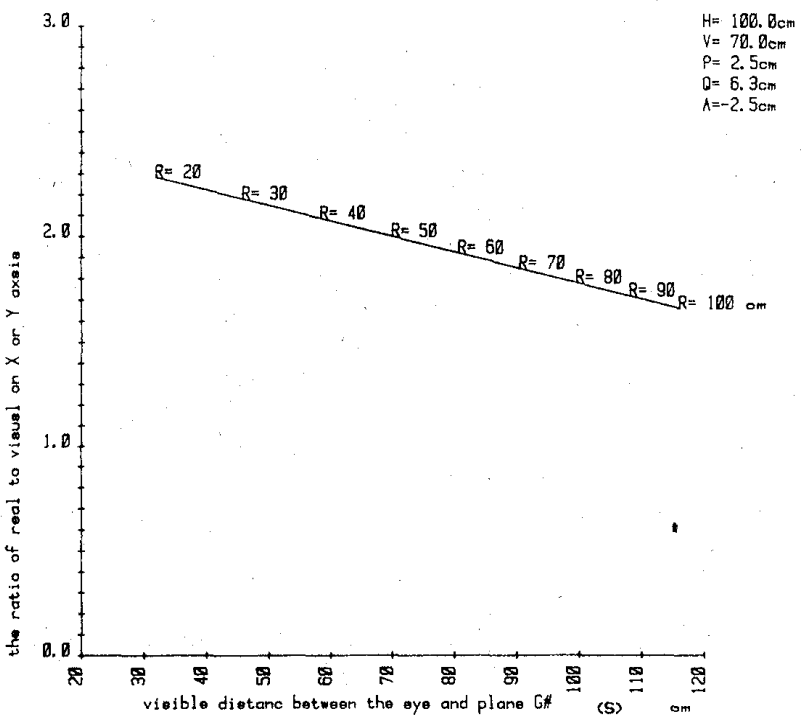

Fig. 7. Magnification ratio of $\mathrm{X}$ or $\mathrm{Y}$ axis.

$$
\begin{aligned}
& A=-2.5 \mathrm{~cm} \\
& P=2.5 \mathrm{~cm}
\end{aligned}
$$




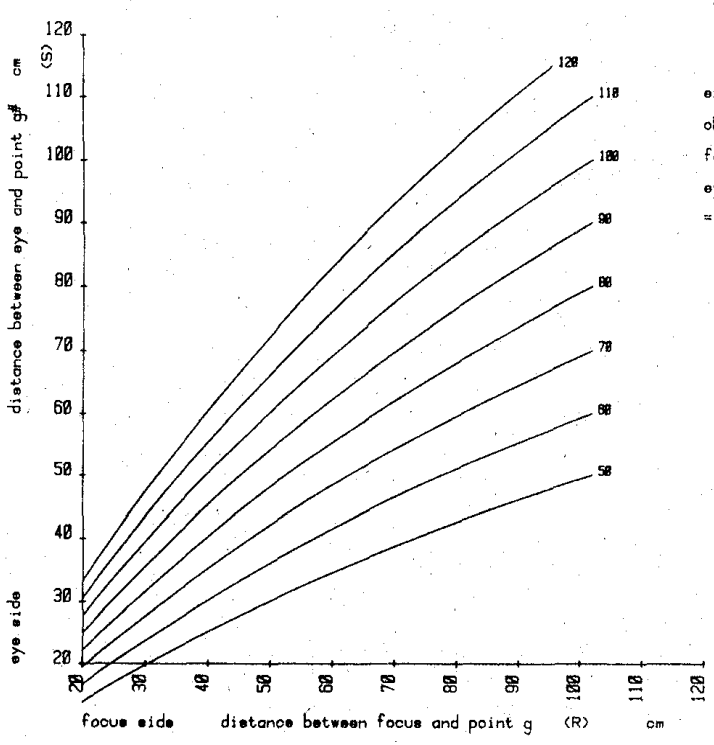

Fig. 8. The relation between real $Z$ axis and visual $Z$ axis.

$\mathrm{V}=50 \mathrm{~cm}$ to $120 \mathrm{~cm}$, step $10 \mathrm{~cm}$

$$
\mathrm{P}=4 \mathrm{~cm}
$$

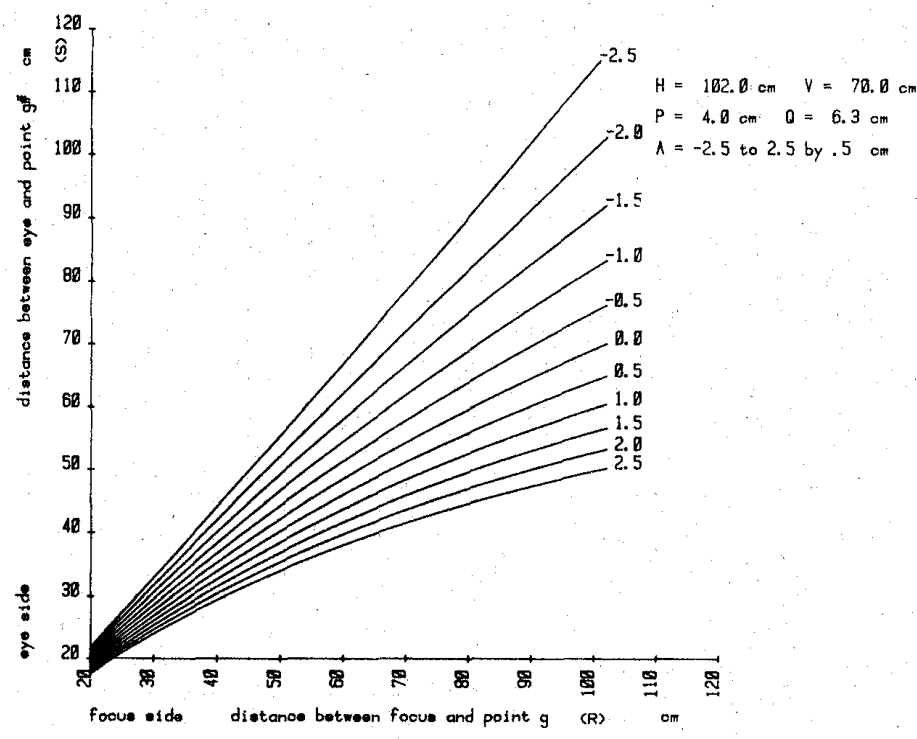

Fig. 10. The relation between real $Z$ axis and visual $Z$ axis.

$$
A=-2.5 \mathrm{~cm} \text { to } 2.5 \mathrm{~cm} \text { step } 0.5 \mathrm{~cm}
$$

Fig. 12 は觀祭距離が変化すると直線の勾配が変化す るととを表わす。

\section{このとよは式 4 からあ㫜らかである。}

特異条件のもとでは，公配が 1 の直線になっている.

このときのX，Y軸の㹡大率のグラフを Fig. 13 亿示 す.

$\mathrm{X}, \mathrm{Y}$ 軸の抬大率は 1 , 従ってこの条件のもとでは, 被写体之立体模像（再生像）のX，Y，ZOS3 軸は 1 対 1 の対応関係化あるとと走す。

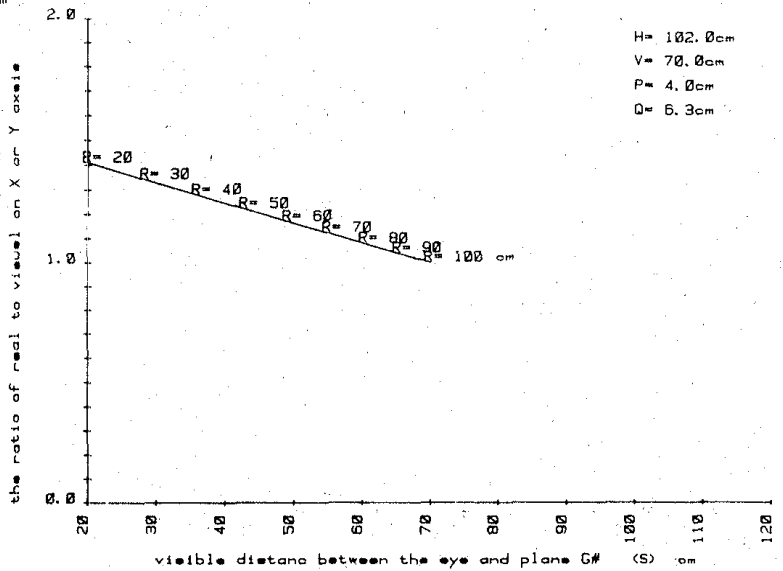

Fig. 9. Magnification ratio of $X$ or $Y$ axis. $A=0$

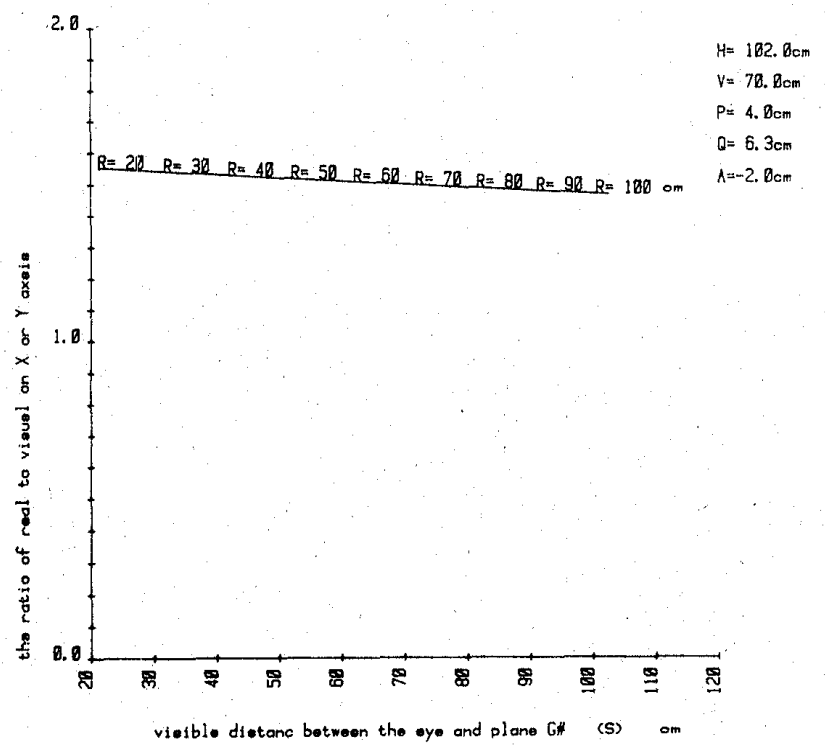

Fig. 11. Magnification ratio of $\mathrm{X}$ or $\mathrm{Y}$ axis.

$$
\begin{aligned}
& \mathrm{A}=-2.0 \mathrm{~cm} \\
& \mathrm{P}=4 \mathrm{~cm}
\end{aligned}
$$

Fig. 14は特異条件であっても，フィルムの配置誤差が 加和った場合には，非直線㱏が生じることを示してい る.

Fig. 15は瞳孔間距離が $6.3 \mathrm{~cm} \pm 0.5 \mathrm{~cm}$ のグラフで,ほ ぼ值線に近い曲線であるとわかる。

\section{6. 考 察}

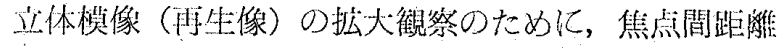
の短かな撮影をし，観祭の際に，フィルム配置誤差を加 


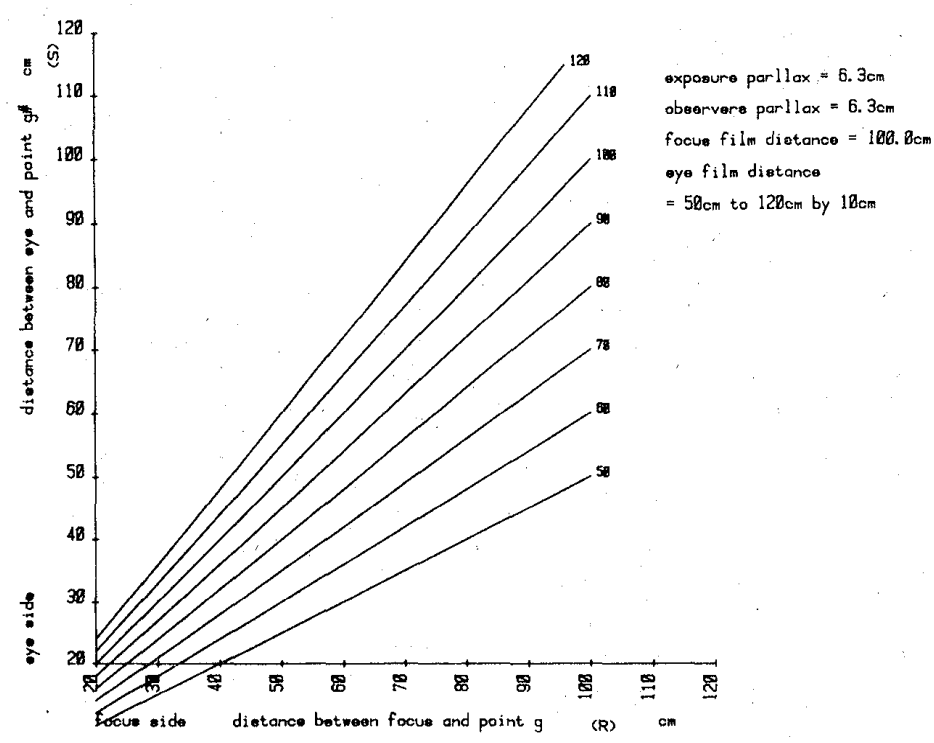

Fig. 12. The relation between real $Z$ axis and visual $Z$ axis.

$\mathrm{V}=50 \mathrm{~cm}$ to $120 \mathrm{~cm}$ step $10 \mathrm{~cm}$ $\mathrm{P}=\mathrm{Q}=6.3 \mathrm{~cm}$

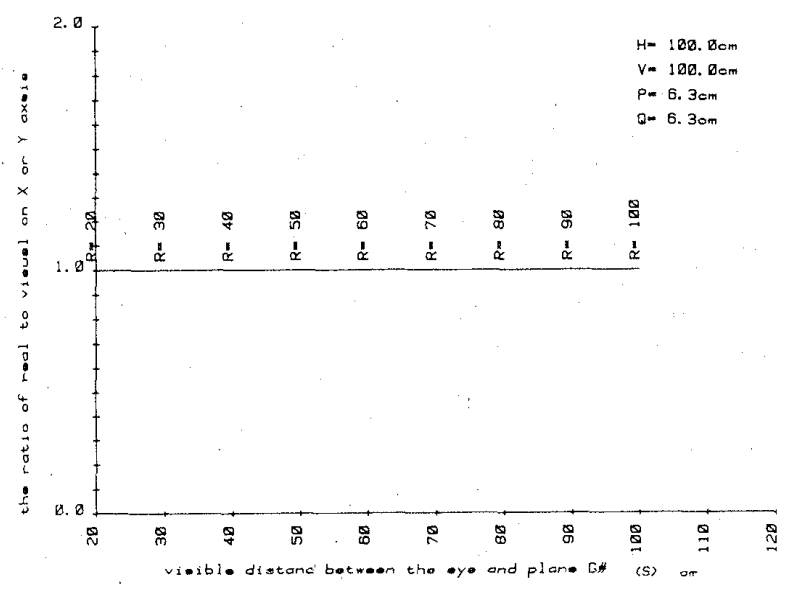

Fig. 13. Magnification ratio $\mathrm{X}$ or $\mathrm{Y}$ axis $\mathrm{A}=0$

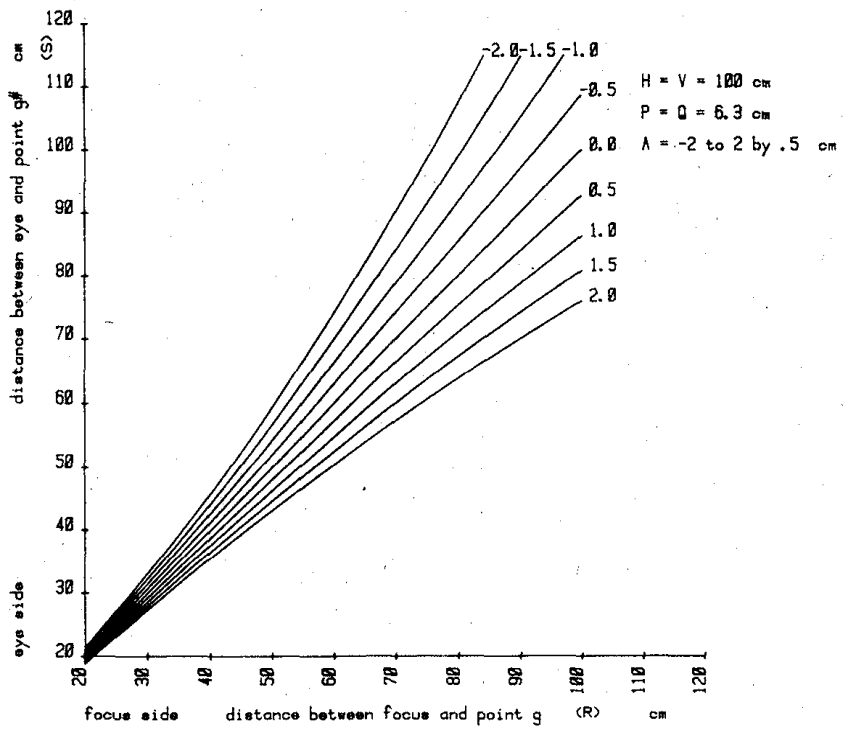

Fig. 14. The relation between real $Z$ axis and visual $Z$ axis.

$\mathrm{A}=-2.5 \mathrm{~cm}$ to $2.5 \mathrm{~cm}$ step $0.5 \mathrm{~cm}$

える方法は，X，Y軸の拔大率とZ軸の拡大率が異なっ てしまい，観祭される立体模像は，歪像亡なる。

歪の小さな立体模像老得るためには，特異条件を满足 させるような体撮影，観察でなければならない。

被写体のM倍の立体模像でなく，1刘1の立体模像で あっても，視㑇老大きくすれば，大きく見えてくる。

視角を大きくするためには，Fig.16亿示すように，焦 点一被写体間距離定知かくすればよいことになる。

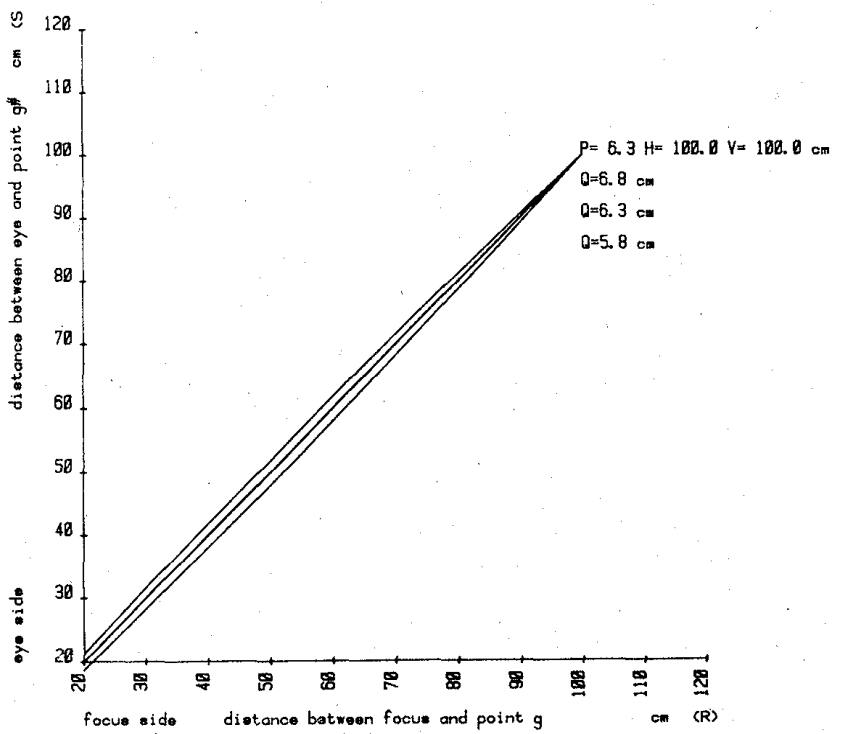

Fig. 15. The relation between real $Z$ axis and visual $Z$ axis.

$\mathrm{Q}=6.3 \mathrm{~cm} \pm 0.5 \mathrm{~cm}$

Fig. 17は特異条件で撮影し，焦点一被写体間距離の巽 なる 2 組の立体写真である.Fig. 17と向に被写体と 1 刘 10 刘応関係を特つ立体模像が得られるが，焦点一被写 体間距離の溉い方が大きく見える立体模像となる。

Fig. 16でわかるよう亿視㑇を決定する因子は，焦点一 被写体間距離で，被写体一フィルム間距離ではない点は 注目すべき事項である。したがって被写体一フィルム間 距離はあまり閏題にしなくともよいか，短い方が同一サ 


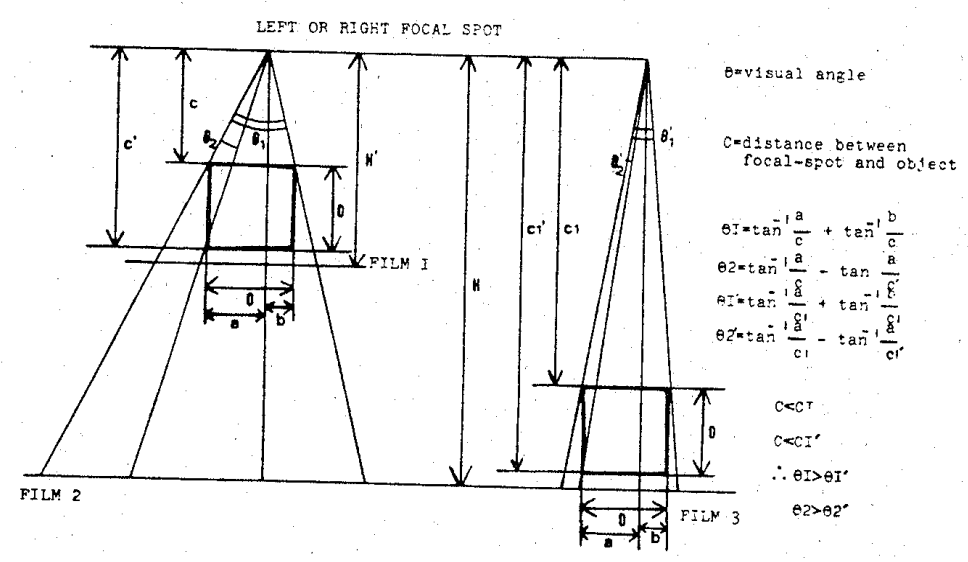

Fig. 16. The relation between object and visual angle.

イズのフィルムを使用した場合, 視野が広くな る.

\section{7. 結 論}

歪みが小さく，且つ大きく見える立体模像を 観祭するためには, 焦点間距離を観察者の瞳孔 間距晟に等しくし（打およそ $6.3 \mathrm{~cm}$ ) 焦点一被 写体闑距離を短汃くした撮影を行なう，得られ た立体写真を観祭する場合认はフフィルム配置 望差をできるだけ小さくする。

また焦点つィルム間距離に等しい瞳孔一フィ ルム閪距髉にする。

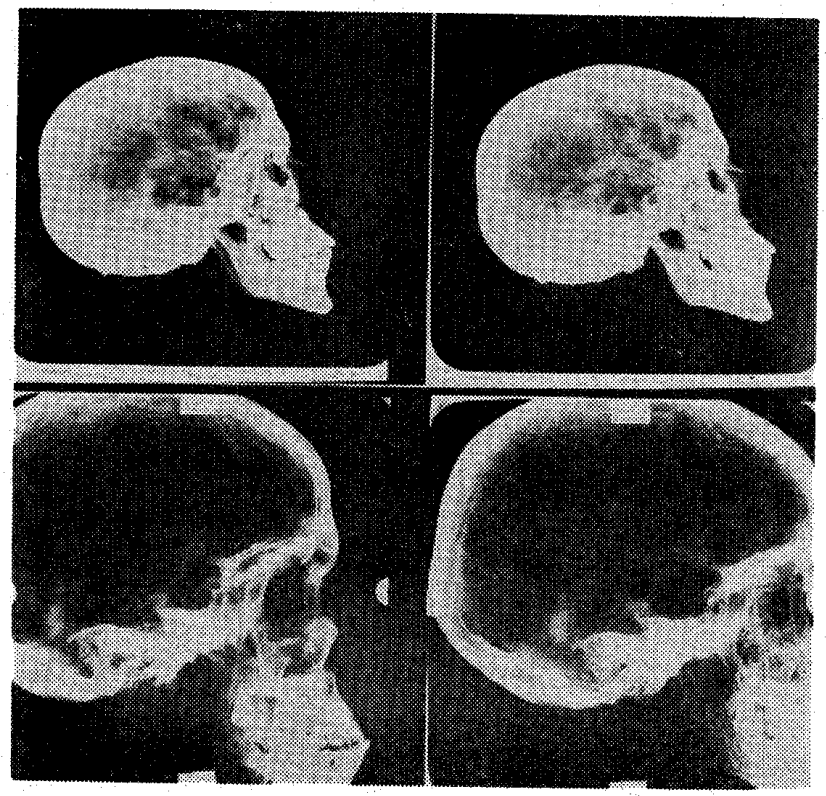

厳密には，焦点一フィルムの座標関係之矌孔一フィル ムの座標関係は一致しなければならない。

稿を終わるにあたり，御校閲いただきました当放射線 科学教室木村和衛教授に深く感謝の意を表します。

\section{文 献}

1) Kunio Doi: Application of Longitudinal Magnification Effect to Magnification Stereoscopic Angiography., Radioiogy, 124, 395--401, (1977)

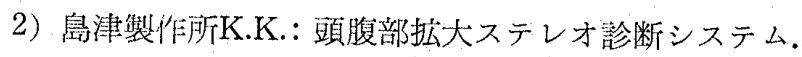
セールスガイド, (1980.12.23)

Fig. 17. Comparison of stereoscopic image on skeleton in long focus-object distance, with short focus-object distance. 